\title{
Effect of duration of phototherapy on serum calcium level in newborn with neonatal jaundice
}

\author{
Chandrashekar B ${ }^{1}$, Venugopal $\mathrm{S}^{2}$, Veeresh S $\mathrm{M}^{3}$ \\ ${ }^{1}$ Dr. Chandrashekar B, Assistant Professor, ${ }^{2}$ Dr.Venugopal S, Assistant Professor, ${ }^{3}$ Dr. Veeresh S M Shivamogga, Senior \\ Resident; all authors are affiliated with Department of Pediatrics, Institute of Medical Sciences, Shivamogga, Karnataka, \\ India
}

Address for Correspondence: Dr Chandrashekar B, Assistant Professor, Department of Pediatrics, Shivamogga Institute of Medical Sciences (SIMS), Shivamogga, Karnataka, India. Email:chandrashekarb2007@yahoo.com,

\begin{abstract}
Introduction: Hyperbilirubinemia (jaundice) is a common and in most cases, benign problem in neonates. Treatment options available for neonatal jaundice are phototherapy, exchange transfusion and pharmacological therapy. Hypocalcaemia is one of the know side effects of phototherapy. Objective: Effect of duration of phototherapy on serum calcium level in newborn with neonatal jaundice. Methods: Design: A prospective study Setting: A tertiary care center of Karnataka (SIMS, Shivamogga). Participants: 100 full term and 100 preterm neonates with gestational age between 34 to 42 weeks were included in study. Main outcome measures: Blood was drawn from these neonates to measure serum bilirubin and serum calcium at the time of initiation of phototherapy ( 0 hours) and at 24,36, 48 hours of phototherapy. Results: Incidence was $48 \%$ in preterm and $14 \%$ in term neonates. Incidence of hypocalcaemia according to duration of phototherapy being, 2 out of $24(8 \%)$ at $24 \mathrm{hrs}$ of PT, 15 out of $73(21 \%)$ at $36 \mathrm{hrs}$ of PT, 45 out of 103 (44\%) at 48hrs of phototherapy. Out of which incidence was more in preterm than in term neonates, more in SGA neonates then AGA. Incidence is not affected by sex of newborn and mode of delivery and parity of mother. Conclusion: These values show that incidence of hypocalcaemia is a significant side effect of phototherapy and more being in preterm and SGA neonates. So while starting phototherapy for neonatal jaundice, one need to be cautious about serum calcium status.
\end{abstract}

Key words: Hypocalcaemia, Neonates, SGA- small for gestational age, AGA- appropriate for gestational age TSB= total serum bilirubin, $\mathrm{PT}=$ phototherapy.

\section{Introduction}

Hyperbilirubinemia (jaundice) is a common and in most cases, benign problem in neonates. Jaundice is observed during first week of life in approximately $60 \%$ of term neonates and in $80 \%$ preterm neonates [1]. Jaundice is attributable to physiological immaturity of neonates to handle increased bilirubin production. Visible jaundice usually appears between 24-72 hours of age [2]. Treatment options available for neonatal jaundice are phototherapy, exchange transfusion and pharmacological therapy [2]. And out of which phototherapy is one of the routine and safest methods for management of hyperbilirubinemia [3]. Phototherapy can produce adverse effects such as dehydration, temperature instability, skin rashes, loose stool, retinal damage, hypocalcaemia, bronze baby syndrome, redistribution of blood flow and genotoxicity [3].

Manuscript received: $8^{\text {th }}$ October 2014

Reviewed: $17^{\text {th }}$ October 2014

Author Corrected: $24^{\text {th }}$ October 2014

Accepted for Publication: $31^{\text {th }}$ October 2014
Hypocalcaemia is one of the know side effects of phototherapy. This effect is because of decrease secretion of melatonin from pineal gland, which is needed to inhibit hypocalcaemia action of serum cortisol [4,5]. Serum calcium is crucial for many biochemical processes, including blood coagulation, neuromuscular excitability, cell membrane integrity and function, and cellular enzymatic and secretary activity $[6,7]$.

Most of the reports with regards to incidence of hypocalcaemia in phototherapy are from studies conducted at metropolitan cities in India and other countries and serum calcium level checked at the starting of phototherapy and at 48hours of phototherapy and no systematic studies have been carried out in relation to duration (at 24hrs,36hrs, 48hrs) of phototherapy. Hence, it is the need of the hour to investigate the effect of duration of phototherapy on serum calcium level in neonates with hyperbilirubinemia and incidence of hypocalcaemia in those neonates. 


\section{Amis and objectives}

To assess the effect of duration of phototherapy on serum calcium level in newborn with neonatal jaundice

\section{Materials and Method}

Source of data: This study conducted in SIMS, Shivamogga. 200 neonates with neonatal jaundice were included in this study who is admitted to Neonatal Intensive Care Unit at SIMS, shivamoggal. Study done over a period of 1 year from June 2013 to May 2014.

\section{Blood screening}

- Blood drawn from the peripheral hand or feet veins of each neonate. Sterile, disposable syringes and needles, and proper tubes were used.

- The blood samples were analyzed at SIMS, Shivamogga clinical laboratory for Serum TSB and serum calcium at the time of admission and every 12 hourly.

- Pretest and post-test counseling is given to parents. After written consent from the parents, those neonates fulfilling the above mentioned criteria are subjected to blood test.

- And "hypocalcaemia defined as <7mg/dl"[8]

Type of study: Hospital based prospective study.

\section{Inclusion criteria}

1. Full-term neonates (37 completed weeks to 41 weeks) with unconjugated hyperbilirubinemia requiring phototherapy.
2. Preterm neonates ( 34 weeks to less than 37 completed weeks) with unconjugated hyperbilirubinemia requiring phototherapy.

Requirement of phototherapy decided according to guidelines of phototherapy graph by American academy of pediatrics ${ }^{6}$.

\section{Exclusion criteria}

Newborn,

1. With jaundice in first 24 hours of life.

2. Born To a diabetic mother, hypothyroid mother, hyperparathyroidism mother

3. With APGAR score of less than 7 at 5 minutes of birth.

4. Whose mother had history of taking anti-convulsants.

5. Fed with Cow's milk.

6. Who had exchange transfusion.

7. With jaundice lasting more than 14 days of life.

8. With sepsis.

9. Hypocalcaemia before starting of phototherapy

10. Preterm $<34$ weeks

Stastical methods: Data analysis was performed using statistical package of social science (SPSS) version 16.0 for windows.

1) Proportions will be compared using chi-square test and student $\mathrm{t}$ test.

2) Mean between the groups will be compared using Ttest or ANNOVA.

\section{Results}

The study consisted of total 200 neonates (100 full term and 100 preterm). Study consisted of 115(57.5\%) male and $85(42.5 \%)$ female neonates. $123(61.5 \%)$ neonates were born by normal veginal delivery and $77(38.5 \%)$ were LSCS. $133(66.5 \%)$ neonates were born to primipara and 67(33.5\%) neonates were born to multipara.

These babies were put on phototherapy (PT) and blood was drawn from these neonates for serum bilirubin and serum calcium at the time of starting of phototherapy and every 12 hourly.

At 12 hours of PT no neonates completed PT. At 24hours of PT 24 neonates, at 36hours 73 neonates and at 48 hours 103 neonates completed phototherapy as shown in table1. Neonates who completed PT at 24hours were grouped as group A, at 36 hours were grouped as group B and at 48hours were grouped as group C and TSB and serum calcium level were taken at their respective completion period.

Table-1: Distribution of neonates depending on duration of phototherapy

\begin{tabular}{|c|c|c|c|}
\hline & Pre term & Term & Total \\
\hline 24hrs (group A) & 9 & 15 & 24 \\
\hline 36hrs (group B) & 37 & 36 & 73 \\
\hline 48hrs (group C) & 54 & 49 & 103 \\
\hline
\end{tabular}

So most of neonates $(>50 \%)$ needed phototherapy for $\geq 48$ hours. 
Table-2: Average TSB and serum calcium level in each group

\begin{tabular}{|c|c|c|c|c|c|c|}
\hline & \multicolumn{2}{|c|}{ Average TSB(mg/dl) } & \multirow{2}{*}{$\begin{array}{c}\text { Difference } \\
(\mathrm{mg} / \mathrm{dl})\end{array}$} & \multicolumn{2}{|c|}{ Average s. ca(mg/dl) } & \multirow{2}{*}{$\begin{array}{c}\text { Difference } \\
(\mathrm{mg} / \mathrm{dl})\end{array}$} \\
\hline & Pre PT & Post PT & & Pre PT & Post PT & \\
\hline 24hrs (group A) & 17.22 & 11.92 & 5.3 & 9.08 & 8.33 & 0.75 \\
\hline 36hrs (group B) & 17.78 & 13.12 & 4.66 & 9.45 & 8.25 & 1.2 \\
\hline 48hrs (group C) & 18.84 & 11.12 & 7.72 & 9.34 & 7.53 & 1.81 \\
\hline
\end{tabular}

From table it's clear that reduction of calcium is more with increasing duration of phototherapy and chances of developing hypocalcaemia increases with increasing duration.

Table-3: Incidence of phototherapy induced hypocalcaemia depending on duration of phototherapy

\begin{tabular}{|c|c|c|c|c|}
\hline & Preterm & Term & total & P value \\
\hline 24hrs (group A) & 1 out of $9(11 \%)$ & 1out of $15(6 \%)$ & 2 out of $24(8 \%)$ & $<0.05$ \\
\hline 36hrs (group B) & 10 out of $37(27 \%)$ & 5 out of $36(14 \%)$ & 15 out of $73(21 \%)$ & $<0.05$ \\
\hline 48hrs (group C) & 37 out of $54(68.5 \%)$ & 8 out of $49(16 \%)$ & 45 out of $103(44 \%)$ & $<0.05$ \\
\hline Total & $48($ out of 100$)$ & 14(out of 100) & 62(out of 200) & $<0.05$ \\
\hline
\end{tabular}

From above table it is seen that $\mathrm{p}$ value $(<0.05)$ is significant at 24,36 and 48 hours.

And number of neonates developing hypocalcaemia increases with increasing duration of PT and effect of duration of phototherapy more in preterm compared to term.

\section{Discussion}

This study is undertaken to confirm effect of duration of phototherapy on serum calcium level and incidence of hypocalcaemia in neonates with jaundice and recommendation to prevent it. Study is conducted in newborn unit SIMS, Shivamogga over a year from June 2013 to May 2014.

Jaundice is a well-known clinical entity in Indian medicine. And phototherapy is one of the best and safe method as a treatment option in neonatal jaundice as described by cremer et al in 1953, Every safe method has its own side effects and even the phototherapy [3]. One of the known side effects of phototherapy is hypocalcaemia ${ }^{2}$.

Neonatal jaundice is a common clinical condition. There is a high prevalence of neonatal hyperbilirubinemia which might be attributed to the high frequency of glucose-6-phosphate dehydrogenase (G6PD) enzyme deficiency. Phototherapy is amongst common therapeutic modalities used in the treatment of uncomplicated neonatal jaundice. So far, several investigations have been conducted to determine the safety of phototherapy in the treatment of neonatal hyperbilirubinemia. Very soon, detrimental effects of phototherapy on eyes and genitalia have been shown. Nonetheless, no change in blood ions/ metabolites has been reported except for calcium concentration; a drop in serum calcium has been noticed in patients undergoing phototherapy.

Phototherapy leads to inhibition of pineal gland via transcranial illumination, resulting in a decline in melatonin level and, in turn, diminishing corticosteron to finally decrease calcium resorption from bones, producing hypocalcemia. This hypothesis, based on studies on rabbit suggests that melatonin, by stimulating corticosteron release, lowers calcium absorption in bones, thus decreasing secretion of melatonin which is secondary to phototherapy causes, bone calcium uptake increases and as a result, hypocalcemia develops

There are many studies conducted to prove that hypocalcaemia is a side of phototherapy. But there are no studies about effect of duration of phototherapy. We conducted the study to observe the effect of duration of phototherapy on serum calcium level and incidence of hypocalcaemia. The study group includes 200 neonates admitted in NICU for neonatal jaundice considering inclusion and exclusion criteria.

We took a cut value of serum calcium of $<7 \mathrm{mg} / \mathrm{dl}$. which is similar to cut of value taken by Arora et al[9], karamifer el al[10], Taheri et al[11]. Our study variables are comparable to karamifer el al, Taheri et al, Therani et al, Egbalian et al[7] and Kumar et al[12]. 
Research Article

After subjecting 200 neonates with jaundice for phototherapy total incidence of hypocalcaemia was $31 \%$. In which incidence was $48 \%$ in preterm and $14 \%$ in term neonates. Incidence of hypocalcaemia according to duration of phototherapy being, 2 out of $24(8 \%)$ at $24 \mathrm{hrs}$ of PT, 15 out of $73(21 \%)$ at $36 \mathrm{hrs}$ of PT, $45 \mathrm{out}$ of $103(44 \%)$ at $48 \mathrm{hrs}$ of phototherapy. Indicating that not only phototherapy per say even the duration also affects incidence of hypocalcaemia. All the previous studies they measured serum calcium at the onset of PT and at the end of PT (commonly at48hrs). No previous studies done serum calcium measurement at different interval.

Table-4: Showing comparison of present study variables and results with other studies

\begin{tabular}{|c|c|c|c|c|c|c|c|}
\hline$P$ value & & $<0.01$ & $<0.05$ & $<0.05$ & & $<0.01$ & \\
\hline $\begin{array}{l}\text { \% incidence of } \\
\text { hypocalcaemia }\end{array}$ & & 43 & 22 & & & & 46 \\
\hline \multirow[t]{2}{*}{$\begin{array}{l}\text { Pre and post PT } \\
\text { S.Ca }(\mathrm{mg} / \mathrm{dl})\end{array}$} & Perm & $\begin{array}{c}9.48 \pm 0.97 \\
\text { to } \\
8.04 \pm 0.88\end{array}$ & $\begin{array}{c}9.53 \pm 0.92 \\
\text { to } \\
9.30 \pm 1.11 \\
\end{array}$ & $\begin{array}{c}9.8 \pm 0.8 \\
\text { to } \\
9.5 \pm 0.92\end{array}$ & $\begin{array}{c}9.46 \pm 0.8 \\
\text { to } \\
9.12 \pm 0.83\end{array}$ & $\begin{array}{c}9.85 \pm 1.23 \\
\text { to } \\
9.09 \pm 0.93\end{array}$ & \\
\hline & Preterm & $\begin{array}{c}9.21 \pm 0.9 \\
\text { to } \\
7.08 \pm 0.7\end{array}$ & $\begin{array}{l}8.73 \pm 1.3 \\
\text { to } \\
8.40 \pm 1.7\end{array}$ & & & & \\
\hline \multirow{2}{*}{$\begin{array}{l}\text { Average birth } \\
\text { weight }(\mathrm{kg})\end{array}$} & Term & 2.98 & 2.88 & & & & \\
\hline & Preterm & 2.003 & 2.077 & & & & \\
\hline \multirow[t]{2}{*}{ Gender } & Female & 78 & 65 & 73 & & & \\
\hline & Male & 122 & 88 & 74 & & & \\
\hline \multirow{3}{*}{$\begin{array}{l}\text { Study } \\
\text { population }\end{array}$} & Term & 100 & 91 & 147 & & & 55 \\
\hline & Preterm & 100 & 62 & & & & 45 \\
\hline & Total & 200 & 153 & 147 & & & 100 \\
\hline Study & & $\begin{array}{l}\text { Present } \\
\text { study }\end{array}$ & $\begin{array}{l}\text { Karamifar } \\
\text { et al }\end{array}$ & $\begin{array}{c}\text { Taheri et } \\
\text { al }\end{array}$ & $\begin{array}{c}\text { Therani et } \\
\text { al }\end{array}$ & $\begin{array}{c}\text { Egbalian et } \\
\text { al }\end{array}$ & $\begin{array}{c}\text { Kumar } \\
\text { et al }\end{array}$ \\
\hline
\end{tabular}

There was a direct relationship between duration of phototherapy and development hypocalcemia. It is recommended that in order to prevent development of hypocalcemia in phototherapytreated newborns, one of two following measures be carried out.

1. Newborns under phototherapy should be given oral calcium as prophylaxis.

2.Parallel to the covering of the eyes that is routinely done to prevent retinal damage, measures be taken for covering head and occipital area of these newborns using a special hat during phototherapy, so that light effect from phototherapy on newborns' pineal gland and consequently melatonin decrease and hypocalcemia is prevented[7].

In one study, it was observed that by administration of melatonin to the newborn rat, it is possible to prevent phototherapyinduced hypocalcemia. It can also be prevented by covering and protection of occipital region of rats. 6 In a study by Dutte, et al,[13] considerable decrease in serum calcium level was observed particularly into premature newborns, and prophylactic administration of calcium for newborns under phototherapy was recommended.

\section{Conclusion}

So in conclusion we need to be careful about calcium status while starting phototherapy for neonatal jaundice. More specifically when duration is $>24$ hours and that to in preterm neonates. And it's better to monitor serum calcium level every 6 to 12 hourly after 24hrs of phototherapy and supplement calcium in preterm neonates and when duration of phototherapy is more than 24 hours.

Acknowledgements: No

Funding: No funding sources

Conflict of Interest: The author declare no conflicts of interest

\section{References}

1. Anthony j,pizza and Barbara j stoll: jaundice and hyperbilirubinemia in newborn. In:kliegman, behaman, Stanton(eds) nelson text book of pediatrics. $18^{\text {th }}$ edition, Philadelphia, saunders, 2008;756 - 57

2. MLP. Gregory, CR Martin, and JP Cloherty neonatal hyperbilirubinemia. In:ClohertyJP, EC Eichenwald, Hansen AR, Ann R Stark (Eds) Manual of neonatal care. $7^{\text {th }}$ edition Philadelphia: LippincottWillems and Wilkins:2012 p 304 - 339 
3. Meharban singh neonatal hyperbilirubinemia In: care of newborn : $8^{\text {th }}$ edition : CBS publishers and distribution: 2015 p $323-348$

4. HarneetSethi, Arvind Saili, and DuttaAK: Phototherapy induced hypocalcemia. Indian pediatrics 1993;30 (12):1403-06

5. Sourabh Dutta. Phototherapy for neonatal jaundice, recent advances and controversies. Journal of Neonatology 2001;1(1):39-44

6. BK Jain, Harmesh Singh, and Daljit Singh, NS Toor: Phototherapy induced hypocalcemia. Indian pediatrics 1998; 35(6):566-67.

7. F Eghbalian, A Monsef: Phototherapy induced hypocalcemia in icteric newborns. IJMS 2002;27(4):16971

8. AIIMS NICU PROTOCOL 2010
9. Arora, S., G. S. Narang, and G. Singh. "Serum calcium levels in preterm and term neonates on phototherapy." Journal of Nepal Paediatric Society 34.1 (2014): 24-28.

10. H Karamifar, N Pishva, GHAmirhakimi: Prevalence of phototherapy induced hypocalcemia. IJMS 2002;27(4):166-68

11. Alizadeh-Taheri, Paymaneh, Negar Sajjadian, and Bahareh Eivazzadeh. "Prevalence of phototherapy induced hypocalcemia in term neonate." Iran J Pediatr; Vol 23.6 (2013).

12. Sameer Kumar Jain. Evaluation of effect of phototherapy on serum calcium level Medical Journal June 2015; 2(6): 316-318

13. Sethi H. Sails A, Dutte Ak: Phototherapy in duced hypocalcemia. J Indian pediatr 1998; 30(12):403-6.

\section{How to cite this article?}

Chandrashekar B. Prevalence of microcytic hypocromic anemia in children with LRTI in the age group of 3 months to $5 y e a r:$ Is iron deficiency anemia a risk factor for LRTI?. Pediatr Rev: Int J Pediatr Res 2014;1(3):9397.doi:10.17511/ijpr.2014.103.06 